\title{
Correction to references
}

Research and Practice in Technology Enhanced Learning

\author{
The original article can be found \\ online at https://doi.org/10.1186/ \\ s41039-020-0123-2; https://doi.org/ \\ 10.1186/s41039-020-00138-4; \\ https://doi.org/10.1186/s41039-020- \\ 0125-0; https://doi.org/10.1186/ \\ s41039-020-0124-1; https://doi.org/ \\ 10.1186/s41039-019-0095-2. \\ Correspondence: info@ \\ biomedcentral.com \\ London, UK
}

\section{Correction to: Wong et al. IDC theory: interest and the interest loop. Research and Practice in Technology Enhanced Learning (2020) 15:3 https://doi.org/10.1186/s41039-020-0123-2}

The references below are incomplete in this article (Wong et al., 2020):

Amabile, T. M. (1996). The motivation for creativity in organizations. Retrieved from.

Freer, P. K. (2009). Boys' descriptions of their experiences in choral music. Retrieved from Atlanta, GA:

The complete references are given below:

Amabile, T. M. (1997). Motivating Creativity in Organizations: On Doing What You Love and Loving What You Do. California Management Review, 40(1), 39-58.

Freer, P. K. (2009). Boys' descriptions of their experiences in choral music. Research Studies in Music Education, 31(2), 142-160.

The original paper has been updated.

Correction to: Cox and Prestridge. Understanding fully online teaching in vocational education. Research and Practice in Technology Enhanced Learning (2020) 15:16 https://doi.org/10.1186/s41039-020-00138-4

The references below are incomplete in this article (Cox \& Prestridge, 2020):

Atkinson, G., \& Stanwick, J. (2016). Trends in VET: Policy and participation. Retrieved from.

Australian Department of Education and Training (2016). Redesigning VET FEEHELP: Discussion paper. Canberra: Australian Government.

Fowler, C. (2017). The boundaries and connections between the VET and higher education sectors: 'Confused, contested and collaborative'. Retrieved from Adelaide:

Griffin, T., \& Mihelic, M. (2019). Online delivery of VET qualifications: Current use and outcomes. Retrieved from Adelaide:

Hodge, S. (2014). Interpreting competencies in Australian vocational education and training: Practices and issues. Retrieved from Adelaide:

Jaggars, S. S., \& Xu, D. (2013). Predicting online student outcomes from a measure of course quality. Retrieved from New York: 
Jensen, L., Price, L., \& Roxå, T. (2019). Seeing through the eyes of a teacher: Differences in perceptions of HE teaching in face-to-face and digital contexts. Studies in Higher Education, 1-11.

Kemmis, R. B., Hodge, S., \& Bowden, A. (2014). Transferable skills in Technical and Vocational Education and Training (TVET): Implications for TVET teacher policies in Australia. The Online Journal for Technical and Vocational Education and Training in Asia, 3.

Productivity Commission. (2011). Productivity Commission research report: Vocational education and training workforce. Retrieved from.

Shi, L., Delahunty, J., \& Gao, X. (2018). Constraints preventing Chinese EFL teachers from putting their stated beliefs into teaching practice. Professional Development in Education, 1-16. doi:https://doi.org/10.1080/19415257.2018.1511455

Trinidad, J. E. (2019). Understanding student-centred learning in higher education: students' and teachers' perceptions, challenges, and cognitive gaps. Journal of Further and Higher Education, 1-11. doi:https://doi.org/10.1080/0309877X.2019.1636214

Westbrook, J., Durrani, N., Brown, R., Orr, D., Pryor, J., Boddy, J., \& Salvi, F. (2013). Pedagogy, curriculum, teaching practices and teacher education in developing countries (Final Report). Education Rigorous Literature Review (2110). Retrieved from Sussex:

The complete references are given below:

Atkinson, G., \& Stanwick, J. (2016). Trends in VET: Policy and participation. Retrieved from https://www.ncver.edu.au/_data/assets/pdf_file/0017/60722/Trends-in-VET.pdf

Australian Department of Education and Training. (2016). Redesigning VET FEEHELP: Discussion paper. Canberra: Australian Government Retrieved from https:// docs.education.gov.au/documents/redesigning-vet-fee-help-discussion-paper

Fowler, C. (2017). The boundaries and connections between the VET and higher education sectors: 'confused, contested and collaborative'. Retrieved from Adelaide: https:// www.ncver.edu.au/_data/assets/pdf_file/0027/158706/Boundaries_-and-_connections_ between_VET_-and-_higher_ed_sectors.pdf

Griffin, T., \& Mihelic, M. (2019). Online delivery of VET qualifications: Current use and outcomes. Retrieved from Adelaide: https://www.ncver.edu.au/_data/assets/pdf_ file/0040/7682296/Online-delivery-of-VET-qualifications.pdf

Hodge, S. (2014). Interpreting competencies in Australian vocational education and training: Practices and issues. Retrieved from Adelaide: https://www.ncver.edu.au/_ data/assets/file/0026/9098/interpreting-competencies-2696.pdf

Jaggars, S. S., \& Xu, D. (2013). Predicting online student outcomes from a measure of course quality. Retrieved from New York: https://ccrc.tc.columbia.edu/media/k2/ attachments/predicting-online-student-outcomes.pdf

Jensen, L., Price, L., \& Roxå, T. (2019). Seeing through the eyes of a teacher: Differences in perceptions of HE teaching in face-to-face and digital contexts. Studies in Higher Education, 45(6), 1149-1159.

Kemmis, R. B., Hodge, S., \& Bowden, A. (2014). Transferable skills in Technical and Vocational Education and Training (TVET): Implications for TVET teacher policies in Australia. The Online Journal for Technical and Vocational Education and Training in Asia, 1(3).

Productivity Commission. (2011). Productivity Commission research report: Vocational education and training workforce. Retrieved from Canberra: https://www.pc.gov. $\mathrm{au} /$ inquiries/completed/education-workforce-vocational/report 
Shi, L., Delahunty, J., \& Gao, X. (2018). Constraints preventing Chinese EFL teachers from putting their stated beliefs into teaching practice. Professional Development in Education, 45(15), 774-789.

Trinidad, J. E. (2019). Understanding student-centred learning in higher education: students' and teachers' perceptions, challenges, and cognitive gaps. Journal of Further and Higher Education, 44(8), 1-11.

Westbrook, J., Durrani, N., Brown, R., Orr, D., Pryor, J., Boddy, J., \& Salvi, F. (2013). Pedagogy, curriculum, teaching practices and teacher education in developing countries (Final Report). Education Rigorous Literature Review (2110). Retrieved from Sussex: https://eppi.ioe.ac.uk/cms/Portals/0/PDF\%20reviews\%20and\%20summaries/Pedagogy\%2 02013\%20Westbrook\%20report.pdf?ver=2014-04-24-121331-867

The original paper has been updated.

Correction to: Mehringer et al. (Swiss) GraphoLearn: an app-based tool to support beginning readers. Research and Practice in Technology Enhanced Learning (2020) 15:5 https://doi.org/10.1186/s41039-020-0125-0

The reference below is incomplete in this article (Mehringer et al., 2020):

Ehri, L. (2005). Development of sight word reading: phases and findings The Science of Reading: A Handbook.

The complete reference is given below:

Ehri, L. C. (2005). Development of Sight Word Reading: Phases and Findings. In M. J. Snowling \& C. Hulme (Eds.), Blackwell handbooks of developmental psychology. The science of reading: A handbook (p. 135-154). Blackwell Publishing. https://doi.org/10. 1002/9780470757642.ch8

The original paper has been updated.

Correction to: Busebaia and John. Can flipped classroom enhance class engagement and academic performance among undergraduate pediatric nursing students? A mixed-methods study. Research and Practice in Technology Enhanced Learning (2020) 15:4 https://doi.org/10.1186/s41039-020-0124-1

The references below are incomplete in this article (Busebaia \& John, 2020):

Bernard, J. S. (2015). Nurse educators' transition to flipped classroom: An interpretive description study.

Diab, B. M., \& Abdel, K. M. (2016). The effect of using flipped classroom instruction on students' achievement in the new 2016 scholastic assessment test mathematics skills in the United Arab Emirates.

The complete references are given below:

Bernard, J. (2015). Nurse educators' transition to flipped classroom: An interpretive description study. (Doctoral dissertation). Retrieved from http://dc.etsu.edu/etd/2603

Diab, B.M., \& Abdel, K.M. (2016). The effect of using flipped classroom instruction on students' achievement in the new 2016 scholastic assessment test mathematics skills in the United Arab Emirates. Electronic Theses and Dissertations. Retrieved from https://scholarworks.uaeu.ac.ae/all_theses/364

The original paper has been updated. 


\section{Correction to: Kim and Xing. Appropriation of affordances of multiliteracies for Chinese literacy teaching in Canada. Research and Practice in Technology Enhanced Learning (2019) 14:1 https://doi.org/10.1186/s41039-019-0095-2}

The references below are incomplete in this article (Kim \& Xing, 2019):

Author. (2013).

Author. (2018).

The complete references are given below:

Kim, M. S. (2013). Teachers as learning designers through teachers' design thinking. In N. Rummel, M. Kapur, M. Nathan \& S. Puntambekar (Eds.), In Proceedings of the 10th International Conference on Computer Supported Collaborative Learning (pp. 493-494). Madison, Wisconsin, USA: International Society for the Learning Sciences.

Kim, M. S., \& Rutgers, J. (2018). Supporting experiential learning through an online learning community. 2018 Learning Outcome Conference. Toronto, Canada.

The original paper has been updated.

Published online: 09 April 2021

\section{References}

Busebaia, \& John (2020). Can flipped classroom enhance class engagement and academic performance among undergraduate pediatric nursing students? A mixed-methods study. Research and Practice in Technology Enhanced Learning, 15, 4 https://doi.org/10.1186/s41039-020-0124-1.

Cox, \& Prestridge (2020). Understanding fully online teaching in vocational education. Research and Practice in Technology Enhanced Learning, 15, 16 https://doi.org/10.1186/s41039-020-00138-4.

Kim, \& Xing (2019). Appropriation of affordances of multiliteracies for Chinese literacy teaching in Canada. Research and Practice in Technology Enhanced Learning, 14, 1 https://doi.org/10.1186/s41039-019-0095-2.

Mehringer, et al. (2020). (Swiss) GraphoLearn: an app-based tool to support beginning readers. Research and Practice in Technology Enhanced Learning, 15, 5 https://doi.org/10.1186/s41039-020-0125-0.

Wong, et al. (2020). IDC theory: interest and the interest loop. Research and Practice in Technology Enhanced Learning, 15, 3 https://doi.org/10.1186/s41039-020-0123-2. 